physicists can rest a little easier than they have in recent years, and one remark made during the hearings has at least not gone unnoticed in the physics community. When Dr McDaniel detailed the AEC request for funds for physical research in 1973, Melvin Price, the committee chairman, remarked, "We may even do better than that."

\section{TECHNOLOGY ASSESSMENT}

\section{Down the Home Straight}

by our Washington Correspondent

THE proposal to establish an Office of Technology Assessment in the legislative branch of the Federal Government seems now to be assured of success. To judge by the tone of hearings on the proposal, held last week by the Senate Rules Committee, the concept is agreed upon by key members of Congress from both political parties, and the chief remaining doubts about the proposed office concern the membership and powers of its management board.

A bill to establish the office was passed early last month by the House of Representatives, but an amendment which caught its sponsors by surprise changed the constitution of the board so that instead of consisting of eleven members, only four of whom would be Congressmen, the office would be directed by a board consisting of five Senators and five members of the House of Representatives. Proposed by Mr Jack Brooks of Texas, the amendment would effectively. mean that the office would be controlled by a joint committee of Congress in place of a rather more independent board of directors.

During the three weeks that elapsed between the bill's passage by the House of Representatives and the hearings before the Senate Rules Committee, Mr Brooks's amendment picked up at least two important supporters in the shape of Senator Gordon Allott and Senator Edward M. Kennedy, both of whom sponsored the original legislation in the Senate. Kennedy testified last week that he agrees with the intent to limit the membership of the governing board only to Congressmen, but suggests that ten should be drawn from each house.

Supporters of the original proposal are, however, concerned that an arrangement in which the Office of Technology Assessment is governed by a joint congressional committee would be less responsive to public demands. As John Davis, chief sponsor of the legislation in the House of Representatives, suggested, for example, Congressmen have little time to devote to extra committee duties, and the proposal could therefore result in less efficient direction.
It seems likely, however, that a compromise will be struck between the original proposals and those contained in $\mathrm{Mr}$ Brooks's amendment. Both $\mathrm{Mr}$ Davis and $\mathrm{Mr}$ Kennedy suggested last week that if the board does consist solely of Congressmen, it should be augmented by an advisory committee drawn from members of the public and perhaps including the Comptroller General and the Director of the Congressional Research Services. The suggestion is that the advisory committee would consist of members of the public drawn from a variety of backgrounds which would be useful in assisting the board of directors in formulating policy for the office.

Testifying in favour of the proposal last week, Dr Philip Handler, president of the National Academy of Sciences, said that he hopes that the office will not regard itself as a policeman whose chief mission is to put a brake on science and technology. He pointed out that technology assessment has in the past been carried out chiefly by an agency that either wants to forward a technology or by a group that wants to prevent it, but rarely has there been a balanced attempt to look at both the benefits and disadvantages of projects.

\section{Short Notes}

\section{Higher Education}

THE chief provisions of the higher education bill that was passed last week by the Senate were almost completely obscured by the acrimonious debate over school busing amendments that were tacked on to the bill. Nevertheless, the Senate reaffirmed its belief that college students should be given federal support grants, the amount being based on parental income, and that colleges should receive general institutional grants tied to the number of federally-aided students that they have enrolled. The student grant provision is expected to increase the number of federally-aided students by a factor of six.

The only major amendment that was made to the bill, compared with the measure that was passed by the Senate last year, was a proposal by Senator Birch Bayh which would prohibit discrimination in colleges and universities on the basis of sex. Bayh's amendment would cut off federal aid from colleges which violate a ban on sex discrimination in their admissions policies and in their staff policies, but it would not apply to those colleges that have traditionally admitted members of only one sex. The bill passed by the House of Representatives, on the other hand, does not include admissions policies in its ban on sex discrimination. Both the House and the Senate bills are now ready to go to a conference committee where fundamental differences in their approach to institutional and student support must be reconciled.

\section{Nuclear Testing}

A MODERATE groundswell of opinion seems to be building up in the Senate in favour of a ban on underground nuclear testing. In January, Senator Edward M. Kennedy introduced a Senate resolution urging the United States to declare a moratorium on underground nuclear testing for as long as the USSR refrains from such tests, and he also called for an immediate start to be made on negotiations for a formal treaty. Similarly, a bipartisan resolution was introduced into the Senate last week by Senator Philip A. Hart and Senator Charles Mathias, urging that negotiations be instigated immediately for a complete ban on nuclear testing. The Hart-Mathias resolution has gained an impressive list of supporters from the scientific community, including Harrison Brown, foreign secretary of the National Academy of Sciences, Franklin Long of Cornell University, Herbert York of the University of California at San Diego, George Wald of Harvard, George Kistiakowsky of Harvard, Polykarp Kusch of Columbia University and Bernard Feld of the Massachussetts Institute of Technology.

\section{Marine Science}

A REPORT published last week by the National Research Council suggests that all the programmes of the United Nations dealing with marine science should be combined in a single and separate organization. Prepared by a panel of the NRC's committee on oceanography, under the chairmanship of Dr William T. Burke of the University of Washington, the report points out that international cooperation on marine science is becoming more important in the light of increases in the variety and intensity of ocean uses, but it questions the ability of present international arrangements to meet the task. Specifically, the panel recommends that a new UN organization should be set up to provide technical support to other international organisations concerned with management of ocean resources and with the political aspects of ocean affairs, and that in the United States the National Oceanic and Atmospheric Administration should be the chief government agency responsible for coordinating international exchange of data on ocean affairs. 